\title{
Genetic Diversity in Populations of Mediterranean Fruit Flies in North-Eastern Brazil
}

\author{
Jéssica S. Cardoso ${ }^{1}$, Sâmela S. Mendes ${ }^{1}$, Ana Maria Waldschmidt ${ }^{1}$, Maria Aparecida Castellani ${ }^{2}$, \\ Iara S. Joachim-Bravo ${ }^{3} \&$ Juvenal C. Silva Jr. ${ }^{1}$ \\ ${ }^{1}$ Department of Biological Sciences, Universidade Estadual do Sudoeste da Bahia, Jequié, Brazil \\ ${ }^{2}$ Department of Plant and Animal Technology, Universidade Estadual do Sudoeste da Bahia, Vitória da \\ Conquista, Brazil \\ ${ }^{3}$ Institute of Biology, Universidade Federal da Bahia, Salvador, Brazil \\ Correspondence: Jéssica S. Cardoso, Department of Biological Sciences, Universidade Estadual do Sudoeste da \\ Bahia, 45205-490, Jequié, Brazil. Tel: 55-(73)-99124-9326. E-mail: jscardoso93@gmail.com
}

Received: May 27, 2021

doi:10.5539/jas.v14n2p70
Accepted: November 21, $2021 \quad$ Online Published: January 15, 2022

URL: https://doi.org/10.5539/jas.v14n2p70

\begin{abstract}
This study aimed at determining the population genetic structure of Mediterranean fruit flies (Ceratitis capitata) in North-eastern Brazil, so as to improve our understanding of the viability of the inter-simple sequences repeat (ISSR) markers in Brazilian populations, along with inferences on population genetic composition which can be used in management programs. For this, ISSR markers were used in groups collected from four municipalities in this region. Primers were polymorphic, revealing moderate expected heterozigosity, with $80 \%$ of the variation occurring within populations and moderate structure. Bayesian analysis revealed $\mathrm{K}=3$, consistent with pairwise $\mathrm{F}_{\mathrm{ST}}$ and indicating low structure between Barra do Choça and Planalto, and moderate structure between Caraíbas and Planalto. Data indicated high diversity, suggesting two interpretations: the analyzed populations arose from a single population and are now under structuring processes, or populations had different origins, but are currently connected by gene flow. Thus, ISSR primers were affective in obtaining information about genetic structure of $C$. capitata populations in North-eastern Brazil, as evidenced by high polymorphism and separation or grouping of populations according to their allelic compositions. Furthermore, this paper provides useful information for understanding the genetic diversity, population structure and gene flow of $C$. capitata populations in this region and developing regional strategies for the control and management of the species.
\end{abstract}

Keywords: Ceratitis capitata, fruticulture, genetic structure, Inter-Simple Sequence Repeat (ISSR) markers, molecular marker

\section{Introduction}

Having originated in Africa, Ceratitis capitata Wiedemann (1824) (Diptera: Tephritidae) is considered a pest insect, as it uses fruits as hosts for larval development, which damages fruits and renders them inappropriate for consumption and commercialization. Also known as Mediterranean fruit fly (moscamed), C. capitata was first recorded in Brazil in 1901, in the State of São Paulo, and since then it has expanded its range and adapted to diverse host fruits and environmental conditions, occurring currently in 23 States (Trassato et al., 2017).

Brazil is the third largest world producer of fruits (representing $4.8 \%$ of the total production), generating approximately 40 million tons (Andrade, 2017). According to the Brazilian Institute for Geography and Statistics (2016), research on municipality-level agricultural production indicated that Brazilian fruit production recorded a R \$ 33 billion profit. Mediterranean fruit flies have a negative impact Brazilian fruit production, causing annual losses of about 1 billion dollars due to fruit damage (Godoy et al., 2011).

North-eastern Brazil has fruit production as one of its main agricultural activities, with a cultivated area of about 2 million hectares (Vidal \& Ximenes, 2016). According to Vidal (2018), this region accounted for around 28\% of the national production of fruits in 2016, evidencing the great economic and social importance of this activity for the region.

Despite the economic importance of $C$. capitata for fruit production and the governmental investment in pest control in North-eastern Brazil, there is as noticeable lack of genetic population studies of the species in this 
region. Moscamed genetic structure has been studied using molecular markers, such as allozymes, mitochondrial DNA, RAPD and microsatellite markers. However, these studies have explored macrogeographic aspects, focusing mainly on colonization events. By contrast, few studies have considered aspects of microgeographic population structure (Gasperi et al., 2002; Alaoui et al., 2010; Karsten et al., 2013; Arias et al., 2018).

Obtaining knowledge about the genetic structure of $C$. capitata populations is very important for understanding the population history of the species, as well as assisting to plan successful eradication programs, which can help to mitigate damage to crops caused by Moscamed (Kurd et al., 2020; Deschepper et al., 2021).

Studies on the genetic structure and diversity, as well as the dispersal patterns of the species, are essential to understand its risk of invasion and damage to agriculture, making it possible in the future to contribute to the development of control strategies in this region (Karsten et al., 2013; Kurd et al., 2020).

Therefore, studies on genetic variability are important for making inferences about population structure, providing information on the level of genetic variability and differentiation between populations as well as on gene flow, which can support control methods. Accordingly, this study aimed at determining the genetic population structure of $C$. capitata in North-eastern Brazil, so as to improve our understanding of the viability of ISSR markers in Brazilian populations, along with inferences on population genetic composition which can be used in management programs.

\section{Material and Methods}

\subsection{Collection of Biological Material}

Fruit samples were collected in 2014, in the municipalities of Barra do Choça (BA), Planalto (BA), Caraíbas (BA)

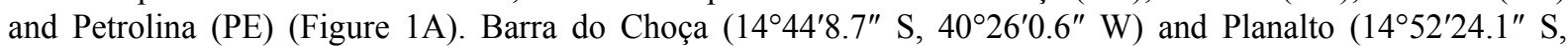
$\left.40^{\circ} 37^{\prime} 50.8^{\prime \prime} \mathrm{W}\right)$ are located in a region with climate ranging from subhumid to dry and semiarid and dry, respectively (SEI, 2019). These municipalities located in South-western Bahia are important producers of arabica coffee (Coffea arabica L.), and host fruits were collected in two equidistant tillages $(40 \mathrm{~km})$. Coffee plantations were surrounded by domestic orchard of diverse fruits, such as papaya, passion fruit, lemon, lime, juá, jamel and tangerine. 


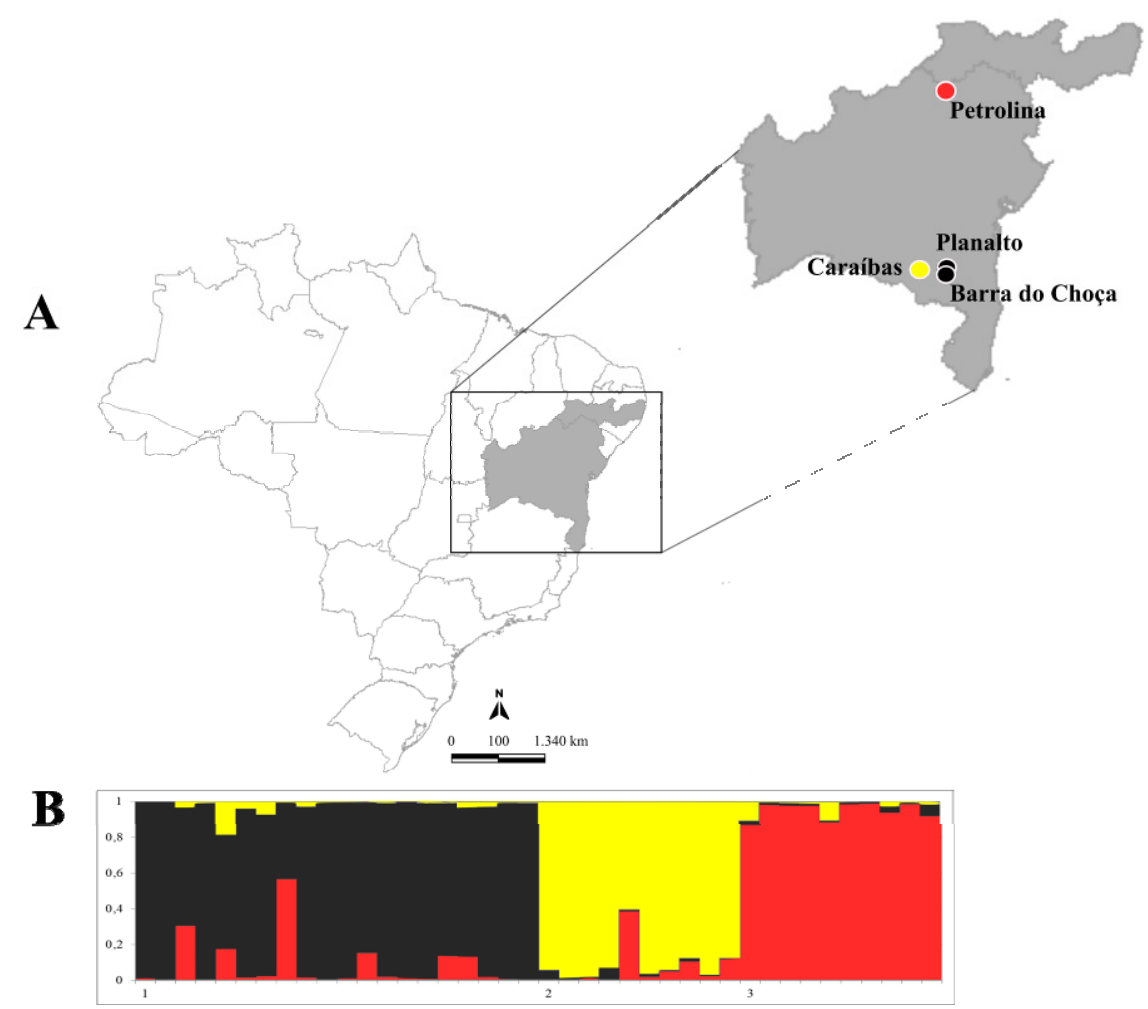

Figure 1. Analysis of samples of Ceratitis capitata. (A) Map indicating collections sites of analyzed C. capitata samples, with three sites in the State of Bahia (Caraibas, Planalto and Barra do Choça) and one site in the State of

Pernambuco (Petrolina); (B) Cluster analysis by Structure with $\mathrm{k}=3$, representing allelic composition of $C$. capitata. Vertical lines represent individuals and colours indicate cluster. Different colours in the same individual indicate the percentage of the genome which is inherited from each cluster. Sites: (1) Barra do Choça and Planalto;

(2) Caraíbas; and (3) Petrolina

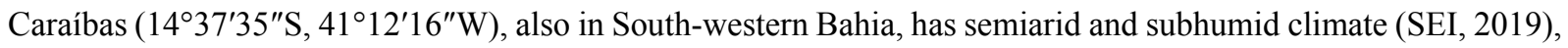
and is remarkable for its production of mango, coconut and Annonaceae, of which mago fruits were sampled. Petrolina $\left(9^{\circ} 04^{\prime} 17^{\prime \prime} \mathrm{S}, 40^{\circ} 19^{\prime} 06^{\prime \prime} \mathrm{W}\right)$ has semiarid climate (SEI, 2019) and is nearby Juazeiro, BA. Together, they comprise the most important center of fruit production in Brazil, known as "Submédio São Francisco". Only mango fruits were sampled there. Around orchards, there were other Mediterranean fruit fly hosts, mostly grapes and banana.

Fruit samples were taken to the Entomology Laboratory at the State University of South-western Bahia (UESB), in Vitória da Conquista (BA), where they were stored in plastic trays with vermiculite as substrate for pupation. After 13 days, fruits were surveyed for pupae, which were transferred to plastic bowls closed with voil tissue for adult emergence. Among emerged adults, samples of male and female individuals were sampled for each locality, appropriately tagged and sent to the Laboratory of Molecular Genetics of UESB, in Jequié (BA), where they were stored at $-20^{\circ} \mathrm{C}$.

\subsection{Extraction of Genomic DNA}

Adult females of $C$. capitata were used for extraction of genomic DNA, using the extraction kit Wizard Genomic DNA Purification (PROMEGA) according to manufacturer instructions.

Afterwards, samples were coloured with GelRed and subjected to electrophoresis in $0,8 \%$ agar gel submersed in TBE $1 \mathrm{X}$ (Tris-Borato $90 \mathrm{mM}$ and EDTA $1 \mathrm{mM}$ ), in order to quantify and assess the integrity and purity of extracted DNA.

\subsection{Amplification of Genomic DNA}

The amplification reaction for analysis of ISSR (Inter Simple Sequence Repeat) was used following a method modified from Zietkiewicz et al. (1994), using primers UBC (British Columbia University) 808, UBC 810, UBC 846, UBC 853, UBC 855 and UBC 886. Each amplification reaction consisted of a $10 \mu \mathrm{L}$ mix, containing $0.4 \mu \mathrm{M}$ 
of primer, $1.5 \mathrm{mM}$ of $\mathrm{MgCl}_{2}$ (INVITROGEN), $0.1 \mathrm{mM}$ of dNTP (dATP, dCTP, dGTP e dTTP) (INVITROGEN), $1 \times$ of Buffer (INVITROGEN), $0.1 \mathrm{U}$ of Taq DNA-polimerase Platinum (INVITROGEN), $6.9 \mu \mathrm{L}$ sterile water for injection (ISOFARMA) and $1 \mu \mathrm{L}$ of extracted genomic DNA. The mix was incubated using a thermocycler (Applied Biosystems), following an initial step of denaturation at $94{ }^{\circ} \mathrm{C}$ for five minutes, then 45 cycles in three steps: (i) denaturation at $94{ }^{\circ} \mathrm{C}$ for 1 minute; (ii) annealing of primers at $53{ }^{\circ} \mathrm{C}$ for 45 seconds; and (iii) extension at $72^{\circ} \mathrm{C}$ for 2 minutes. Lastly, there was an extension step at $72^{\circ} \mathrm{C}$ for 6 minutes.

Amplification products were submitted to electrophoresis in Agar gel at 1.2\%, coloured with GelRed Nucleic Acid (Biotium). Amplified fragments were visualized in ultraviolet light and photographed with L-PIX Transilluminator Molecular Imaging (Loccus Biotecnologia).

\subsection{Statistical Analysis}

Population genetic diversity was estimated through analysis of the products of amplification according to presence (1) or absence (2) of bands.

Using GenAlEx v.65 (Peakall \& Smouse, 2012), we calculated the percentage of polymorphic loci, mean expected heterozigosity (He), and ran an Analysis of Molecular Variance (AMOVA), which assessment of genetic structure at two hierarchical levels: within and between populations. We also calculated the population structure index $\left(\mathrm{F}_{\mathrm{ST}}\right)$, which represents the probability that two individuals from two different subpopulations share one identical allele by common descent. Matrices of Nei's distance (Nei, 1978) and pairwise $\mathrm{F}_{\mathrm{ST}}$ were calculated using the mean number of genetic differences between pairs within and between populations.

Using the Isolation by Distance Web Service v.3.23 (Jensen et al., 2005), we performed a Mantel test to analyze the correlation between geographic distance $(\mathrm{km})$ and genetic distance (pairwise $\mathrm{F}_{\mathrm{ST}}$ ).

Bayesian analysis was performed using STRUCTURE v. 2.3.3 (Hubisz et al., 2009), allowing inference on the occurrence of distinct populations, where each individual is assigned to a population according to the allelic frequencies of the analyzed populations. Accordingly, the number of estimated populations $(\mathrm{K})$ varied between 1 and 4, with 10 essays for each population, according to 1,000,000 iterations of Markov Chain Monte Carlo and a burn-in of 100,000. Lastly, results were analysed using STRUCTURE HARVESTER Web v. 0.6.9 (Earl \& Vonholdt, 2012), in other to estimate the number of populations.

\section{Results and Discussion}

Primers generated a total of 99 loci (Table 1) with a high rate of polymorphism (76.52\%), with an average of 16 bands ranging between eight in bands in primer UBC 808 and 27 bands in primer UBC 886. Among analyzed sites, Barra do Choça had the highest percentage of polymorphism (86.87\%) and Petrolina the lowest $(66.67 \%)$.

Table 1. ISSR primer sequences used for the analysis of genetic variability in Ceratitis capitata and their respective numbers of detected loci (bands)

\begin{tabular}{lll}
\hline Primers & Sequence $\left(5^{\prime} \rightarrow 3^{\prime}\right)$ & Number of band \\
\hline UBC 808 & AGAGAGAGAGAGAGAGC & 8 \\
UBC 810 & GAGAGAGAGAGAGAGAT & 22 \\
UBC 846 & CACACACACACACACART & 14 \\
UBC 853 & TCTCTCTCTCTCTCTCRT & 17 \\
UBC 855 & ACACACACACACACAYT & 11 \\
UBC 886 & VDVCTCTCTCTCTCTCTC & 27 \\
\hline
\end{tabular}

The high rate of polymorphic loci was also observed for C. capitata by Beroiz et al. (2012), using ISSR and RAPD markers and by Alaoui et al. (2010) using RAPD.

Analyzed populations had mean expected heterozigosity (He) of 0.282 , which os moderate IF compared to that observed by Alaoui et al. (2010), Who found He to range between 0.323 and 0.232 in 108 loci in Mediterranean fruit fly populations from Marroco, using RAPD-PCR markers.

AMOVA evidenced that $80 \%$ of the variation occurred within populations, consistent with $\mathrm{F}_{\mathrm{ST}}(0.199)$ which indicated statistically significant, moderate structure $(\mathrm{p} \leq 0.001)$. In studies performed in South Africa by Karsten et al. (2013), it was found through sequencing of mitochondrial DNA and microsatellite markers that most genetic variation occurred within populations, which was about two to three times larger than that occurring between populations. 
Analysis of pairwise $\mathrm{F}_{\mathrm{ST}}$ showed moderate structure between populations of Caraíbas and Planalto (0.265), and low structure between Barra do Choça and Planalto (0.030), although all estimates were statistically significant (p $\leq 0.001$ ) (Table 2).

Table 2. Grey values represent the pairwise FST matrix for populations of Ceratitis capitata. Black values indicate Nei's genetic distances between populations.

\begin{tabular}{lllll}
\hline & BC & PL & CA & PE \\
\hline BC & - & 0.039 & 0.169 & 0.128 \\
PL & $0.030^{\text {(ns) }}$ & - & 0.192 & 0.155 \\
CA & 0.202 & 0.265 & - & 0.154 \\
PE & 0.192 & 0.252 & 0.237 & -
\end{tabular}

Note. BC: Barra do Choça; PL: Planalto; CA: Caraíbas; PE: Petrolina. ${ }^{\text {ns }}$ Non-significant distances $(\mathrm{p} \leq 0.001)$.

Nei's genetic distance indicated a higher genetic differentiation between the populations of Planalto and Caraíbas (0.192) and lower genetic differentiation between Barra do Choça and Planalto (0.039) (Table 2).

Mantel's test showed a positive correlation $(r=0.4430)$ between genetic and geographic distance, however this was not statistically significant $(r \geq 0, p=0.2944)$ (Figure 2$)$.

Bayesian analysis indicated $\mathrm{K}=3$, with populations from Barra do Choça and Planalto being very similar with respect to their allelic composition and thus considered as a single population. By contrast, populations from Caraíbas and Petrolina had more differentiated allelic compositions. Despite the separation in three populations, all shared a low percentage of alleles (Figure 1B).

According to the results found, it is possible to make two inferences. First, we can consider that the analyzed populations were all originated from a single population and currently are under structuring processes, with a low proportion of alleles shared by common descent. Other possibility is that populations had different origins, but there is currently gene flow between them, which will tend to homogenize their allelic composition, which may explain the presence of shared alleles in the analysis.

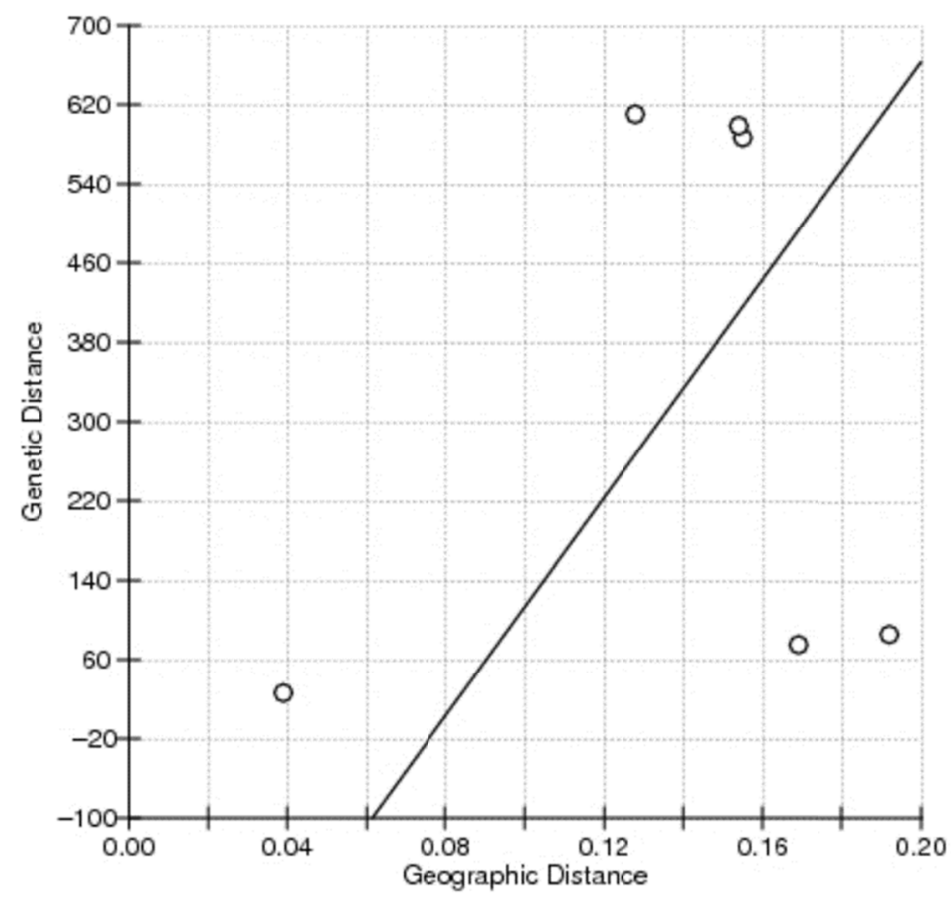

Figure 2. Graph showing the correlation between genetic distance (distance from F ST pair by pair) and geographic distance in populations of C. capitata from Barra do Choça, Planalto, Caraíbas and Petrolina 
Meats and Smallridge (2007) indicated that flight dispersal of C. Capitata occurs between 0.5-9.5 km, and it is probable that only a small percentage of individuals disperse across this distance. Accordingly, $90 \%$ of the individuals analyzed in that study remained within $400-700 \mathrm{~m}$ of the point of release. A similar observation was made in Brazil by a study on the dispersal of sterile males of $C$. Capitata of the tsl Viena 8 lineage, in Pernambuco (Petrolina) (Paranhos et al., 2010) and Bahia (Anagé e Vitória da Conquista) (Silva, 2007). In these studies, there was a concentration of individuals nearby the release site, around 50 and $250 \mathrm{~m}$ of the area of dispersal between 5,000 and $6,000 \mathrm{~m}^{2}$. Thus, by relating geographic distances between Barra do Choça, Planalto, Caraíbas and Petrolina with moscamed's dispersal capacity, it seems possible that these populations share organisms from a similar origin, through import of fruits from a single site, considering that distances between studies sites are much larger than the dispersal capacity of this species. Moreover, fruits containing C. capitata individuals are susceptible to human-driven dispersal mainly through the transportation of fruits containing eggs and immatures.

It should be considered that historical aspect of colonization can influence the observed pattern of population structure. According to Trassato et al. (2017), C. capitata was restricted to South and Southeast Brazil, from which it probably spread towards Northern Brazil through fruit import, especial from the state of São Paulo, a big producer of fruit hosts. However, the possibility of gene flow between populations should not be ignored, independently of fruit import, because the occurrence of orchards between cities could function as stepping stones, and the Mediterranean fruit fly uses both native and introduced fruit hosts (Malavasi, 2009; Zucchi \& Moraes, 2012).

Besides, the process of local adaptation can directly influence genetic composition. According to Weldon et al. (2018), the invasive potential of C. capitata can by supported by adaptation of traits related to bioclimatic tolerance. Considering the environmental conditions of the studied sites, it can be noted that Barra do Choça and Planalto are closer geographically and have similar climatic conditions, which may account for the genetic similarity between individuals. This reflects both adaptive convergence and gene flow between those sites. Although Caraíbas was also geographically close to those sites, when compared to Petrolina, it showed higher allelic differentiation, which may reflect its semiarid climate. Further, genetic differentiation between populations can also be a consequence of adaptation to hosts. If individuals of a given population use a single host, it is likely that this population will have lower genetic diversity compared to another population using diverse hosts (Forister et al., 2012).

Knowledge of genetic relationships between populations of pest insects is essential for control programs. For instance, insecticide resistance can be considered a processes of rapid evolution due to strong selection, with survival of individuals which posses alleles conferring resistance (Hawkins et al., 2019). Gene flow between populations reduces the strength of adaptive divergence between populations by counteracting genetic differentiation. Yet, when local adaptation increases genetic differentiation between populations, gene flow can spread resistant alleles evolved locally to other populations (Karsten et al., 2013). Insecticide resistance is a phenomenon in C. capitata which has been reported for pyrethroids (Arouri et al., 2014) and organophosphates (Elfekih et al., 2014), among other chemicals, and this directly impacts on pest management.

This, if it is confirmed that populations sampled here have originated from a single site are under structuring process, one should adopt different measures to control populations in Caraíbas, Petrolina and the cluster Barra do Choça and Planalto, as these groups are genetically different. However, IF populations have different origins and are experiencing gene flow, then control measures used in the future could be similar, as it is expected that population differentiation will decrease. After confirmation of population origin, strategies of resistance management can concentrate on active plans of monitoring which will allow early detection of resistance alleles in the field.

Furthermore, according to Karsten et al. (2013), results of molecular analysis can used for future evaluation of the Sterile Insect Technique (SIT), considering that genetic diversity should decrease as a consequence PF population decline IF SIT has success in population suppression.

In the current study, we presented results on the population structure of field populations of C. capitata in an important range in North-eastern Brazil. Our findings are an important advance and are crucial for a better understanding of the genetic diversity, population structure and gene flow in populations of C. capitata, as well as for the development of adequate strategies of control and management of this insect in the region. Findings could also apply to other regions, supporting the definition and implementation of more efficient management programs in the country. In future studies, it will be important to concentrate efforts on a number of representative populations and use other molecular markers to confirm the genetic structure of $C$. Capitata populations. 


\section{Conclusion}

ISSR primers used here were effective in obtaining information on the genetic structure of $C$. capitata in the studied populations, revealing high rate of polymorphism and separation or clustering of populations according to their allelic composition.

\section{References}

Alaoui, A., Imoulan, A., El Alaoui-Talibi, Z., \& El Meziane, A. (2010). Genetic structure of Mediterranean fruit fly (Ceratitis capitata) populations from Moroccan Endemic Forest of Argania spinosa. International Journal of Agriculture \& Biology, 12, 291-298.

Andrade, P. F. de S. (2017). Análise da conjuntura agropecuária safra 2016/17. Fruticultura. Parana Governo do Estado. Retrieved from http://www.agricultura.pr.gov.br/arquivos/File/deral/Prognosticos/2017/Fruticultura _2016_17.pdf

Arias, M. B., Elfekih, S., \& Vogler A. P. (2018). Population genetics and migration pathways of the Mediterranean fruit fly Ceratitis capitata inferred with coalescent methods. PeerJ, 6, e5340. https://doi.org/10.7717/peerj.5340

Arouri, R., Le Goff, G., Hemden, H., Navarro-Llopis, V., M'Saad, M., Castañera, P., ... Ortego, F. (2015). Resistance to lambda-cyhalothrin in Spanish field populations of Ceratitis capitata and metabolic resistance mediated by $\mathrm{P} 450$ in a resistant strain. Pest Management Science, 71, 1281-1291. https://doi.org/ $10.1002 /$ ps.3924

Beroiz, B., Ortego, F., Callejas, C., Crespo, P. H., Domínguez, P. C., \& Ochando, M. D. (2012). Genetic structure of Spanish populations of Ceratitis capitata revealed by RAPD and ISSR markers: Implications for resistance management. Spanish Journal of Agricultural Research, 10, 815-825. https://doi.org/10.5424/ sjar/2012103-694-11

Deschepper, P., Todd, T. N., Virgilio, M., De Meyer, M., Barr, N. B., \& Ruiz-Arce, R. (2021). Looking at the big picture: worldwide population structure and range expansion of the cosmopolitan pest Ceratitis capitata (Diptera, Tephritidae). Biological Invasions, 23, 3529-3543. https://doi.org/10.1007/s10530-021-02595-4

Earl, D. A., \& Vonholdt, B. M. (2012). STRUCTURE HARVESTER: A website and program for visualizing STRUCTURE output and implementing the Evanno method. Conservation Genetics Resources, 4, 359-361. https://doi.org/10.1007/s12686-011-9548-7

Elfekih, S., Shannon, M., Haran, J., \& Vogler, A. P. (2014). Detection of the Acetylcholinesterase Insecticide Resistance Mutation (G328A) in Natural Populations of Ceratitis capitata. Journal of Economic Entomology, 107, 1965-1968. https://doi.org/10.1603/EC14166

Forister, M. L., Dyer, L. A., Singer, M. S., Stireman III, J. O., \& Lill, J. T. (2012). Revisiting the evolution of ecological specialization, with emphasis on insect-plant interactions. Ecology, 93, 981-991. https://doi.org/ $10.1890 / 11-0650.1$

Gasperi, G., Bonizzoni, M., Gomulski, L. M., Murelli, V., Torti, C., Malacrida, A. R., \& Guglielmino, C. R. (2002). Genetic differentiation, gene flow and the origin of infestations of the medfly, Ceratitis capitata. Genetica, 116, 125-135. https://doi.org/10.1023/A:1020971911612

Godoy, M. J. S., Pacheco, W. S. P., \& Malavasi, A. (2011). Moscas-das-frutas quarentenárias para o Brasil. In R. A. Silva, W. P. Lemos, \& R. A. Zucchi (Eds.), Moscas-das-frutas na Amazônia brasileira diversidade, hospedeiros e inimigos naturais (pp. 111-131). Macapá: Embrapa.

Hawkins, N. J., Bass, C., Dixon, A., \& Neve, P. (2019). The evolutionary origins of pesticide resistance. Biological Reviews, 94, 135-155. https://doi.org/10.1111/brv.12440

Hubisz, M. J., Falush, D., Stephens, M., \& Pritchard, J. K. (2009). Inferring weak population structure with the assistance of sample group information. Molecular Ecology Resources, 9, 1322-1332. https://doi.org/ 10.1111/j.1755-0998.2009.02591.x

IBGE (Instituto Brasileiro de Geografia e Estatística). (2016). Produção Agrícola Municipal (PAM). Retrieved from https://biblioteca.ibge.gov.br/visualizacao/periodicos/66/pam_2016_v43_br.pdf

Jensen, J. L., Bohonak, A. J., \& Kelley, S. T. (2005). Isolation by distance, web service. BMC Genet., 6, 13. https://doi.org/10.1186/1471-2156-6-13 
Karsten, M., Van Vuuren, B. J., Barnaud, A., Terblanche, J. S. (2013). Population genetics of Ceratitis capitata in South Africa: Implications for dispersal and pest management. PLoS One, 8, e54281. https://doi.org/ 10.1371/journal.pone.0054281

Kumar, L. S., Sawant, A. S., Gupta, V. S., \& Ranjekar, P. K. (2001). Comparative analysis of genetic diversity among Indian populations of Scirpophaga incertulas by ISSR-PCR and RAPD-PCR. Biochemical Genetics, 39, 297-309. https://doi.org/10.1023/A:1012252713056

Kurd, Ö., Doğaç, E., Taşkin, V., \& Göçmen-Taşkin, B. (2020). Estudo genético populacional baseado em marcadores Issr da mosca da fruta mediterrânea Ceratitis capitata (Diptera: Tephritidae). Genetika, 52, 311-322. https://doi.org/10.2298/GENSR2001311K

Malavasi, A. (2009). Biologia, ciclo de vida, relação com o hospedeiro, espécies importantes e biogeografia de tefritideos. In A. Malavasi \& J. F. Virginio (Eds.), Curso Internacional de Capacitação em Moscas-das-Frutas, 5, Vale do São Francisco, Brasil. Biologia, monitoramento e controle de moscas-das-frutas. Juazeiro: Biofábrica Moscamed Brasil.

Meats, A., \& Smallridge, C. J. (2007). Short- and long-range dispersal of medfly, Ceratitis capitata (Dipt., Tephritidae), and its invasive potential. Journal of Applied Entomology, 131, 518-523. https://doi.org/ 10.1111/j.1439-0418.2007.01168.x

Nei, M. (1978). Estimation of average heterozygosity and genetic distance from a small number of individuals. Genetics, 89(3), 583-590. https://doi.org/10.1093/genetics/89.3.583

Paranhos, B. J., Papadopoulos, N. T., Mcinnis, D., Gava, C., Lopes, F. S., Morelli, R., \& Malavasi, A. (2010). Field dispersal and survival of sterile medfly males aromatically treated with ginger root oil. Environmental Entomology, 39, 570-575. https://doi.org/10.1603/EN08309

Peakall, R., \& Smouse, P. E. (2012). GenAlEx 6.5: genetic analysis in Excel. Population genetic software for teaching and research-An update. Bioinformatics, 28(19), 2537-2539. https://doi.org/10.1093/bioinfor matics/bts460

SEI (Superintendência de Estudos Econômicos e Sociais da Bahia). (2019). SIM-Sistema de Informações Municipais. Retrieved from http://sim.sei.ba.gov.br/sim/informacoes_municipais.wsp

Silva, V. E. da S. (2007). Dispersão de machos estéreis de Ceratitis capitata (Wied.) (Diptera: Tephritidae) em agroecossistemas de manga e café na Região Sudoeste da Bahia, Brasil (p. 87, Dissertação (Mestrado), Universidade Estadual do Sudoeste da Bahia, Vitória da Conquista).

Trassato, L. B., Neto, J. L. L. M., Lima, A. C. S., Da Silva, E. S., Teles, B. R., \& Da Silva Carmo, I. L. G. (2017). Primeira ocorrência de Ceratitis capitata (Wied.) no Estado de Roraima, Brasil. Revista Agro@mbiente On-Line, 11, 88-91. https://doi.org/10.18227/1982-8470ragro.v11i1.3594

Vidal, M. F, \& Ximenes, L. J. F. (2016). Comportamento recente da fruticultura nordestina: Área, valor da produção e comercialização. Caderno Setorial Etene. Retrieved from https:/www.bnb.gov.br/documents/ 80223/1138347/3 fruta.pdf/e5f76cc8-c25a-ff08-6402-9d75f3708925

Vidal, M. F. (2018). Fruticultura na área de atuação do BNB. Caderno Setorial Etene. Retrieved from https://www.bnb.gov.br/documents/80223/3686680/35 Fruticultura 2018.1.pdf/b5660ef3-4ea7-7f44-090f-0 $9 \mathrm{~b} 5 \mathrm{a} 3 \mathrm{c} 49097$

Weldon, C. W., Nyamukondiwa, C., Karsten, M., Chown, S. L., \& Terblanche, J. S. (2018). Geographic variation and plasticity in climate stress resistance among southern African populations of Ceratitis capitata (Wiedemann) (Diptera: Tephritidae). Scientific Reports, 8, 1-13. https://doi.org/10.1038/s41598-01828259-3

Zietkiewicz, E., Rafalski, A., \& Labuda, D. (1994). Genome fingerprinting by Simple Sequence Repeat (SSR)-Anchored Polymerase Chain Reaction Amplification. Genomics, 20(2), 176-183. https://doi.org/ 10.1006/geno.1994.1151

Zucchi, R. A., \& Moraes, R. C. B. (2012). Fruit flies in Brazil-Hosts and parasitoids of the Mediterranean fruit fly. Retrieved from http://www.lea.esalq.usp.br/ceratitis 


\section{Copyrights}

Copyright for this article is retained by the author(s), with first publication rights granted to the journal.

This is an open-access article distributed under the terms and conditions of the Creative Commons Attribution license (http://creativecommons.org/licenses/by/4.0/). 